\title{
EFFECTS OF IRRIGATION AND NITROGEN LEVELS ON QUALITATIVE AND NUTRITIONAL ASPECTS OF FIG-TREES (Ficus carica L.) ${ }^{1}$
}

\author{
F.B.T. HERNANDEZ; J.C. MODESTO²; M.A. SUZUKI'; L.S. CORREA \\ Faculdade de Engenharia de tha Solleira - FEIS/UNESP - C.P. 31, CEP: 15378-000 - Tha Solleira,SP \\ K. REICHARDT \\ Departamento de Fistca e Meteorologla - ESALQ/USP, C.P. 9, CEP: 13418-900 - Piractcaba,SP
}

\begin{abstract}
In order to evaluate qualitative and mutritional aspects of fig-trees with respect to six irrigation and six nitrogen levels, at Itha Solteira, SP, Brazil, an experiment was carried out in randomized blocks, with subdivided plots, and four replications. Results showed that in four dates during harvest, only the first analysis (January 2, 1991) showed influence of nitrogen fertilization on fnit soluble solids (brix). There was no significant effect of treatments on pulp/peel relation for the four harvestings. In relation to leaf macronutrient concentration at flowering, water supply influenced $N, P$ and $C a$ concentrations, and nitrogen influenced only Ca concentration. For an average of $10 \mathrm{t}$.ha-1 of mature fruit and $1.3 \mathrm{t}^{-1} \mathrm{ha}^{-1}$ of immature fruit production, there was a nutrient export of about $65 \mathrm{~kg} \cdot \mathrm{ha}^{-1}$ of $\mathrm{N} ; 10 \mathrm{~kg} \cdot \mathrm{ha}^{-1}$ of $\mathrm{P}_{3} \mathrm{O}_{3} ; 44 \mathrm{~kg} \cdot \mathrm{ha}^{-1}$ of $\mathrm{K}_{2} \mathrm{O} ; 35 \mathrm{~kg} \cdot \mathrm{ha}^{-1}$ of $\mathrm{Ca}$ and $9 \mathrm{~kg} \cdot \mathrm{ha}^{-1}$ of $\mathrm{Mg}$.
\end{abstract}

Key Words: fig-trees, irrigation, nitrogen.

\section{EFEITOS DA IRRIGAÇÃO E DE NIVEIS DE NITROGÊNIO EM ASPECTOS QUALITATIVOS E NUTRICIONAIS DA FIGUETRA (Ficus carica L.)}

RESUMO: Para avaliar aspectos qualitativos e nutricionais da figueira em relação a seis nfveis de irrigaçāo e de nitrogênio, desenvolveu-se um experimento em blocos ao acaso, com parcelas subdivididas e com quatro repetições, em Iha Solteira,SP. Os resultados mostraram que em quatro datas de colheita, apenas a primeira analise (2 de janeiro de 91) mostrou influência da fertilizaçāo nitrogenada sobre os s6lidos solúveis (brix) dos frutos. Não houve efeito significativo dos tratamentos sobre a relação polpa/casca, nas quatro colheitas. Com relação à concentração de macronutrientes nas folhas na época de florescimento, o suprimento de água infuenciou as concentrações de $\mathbf{N}$. $P$ e Ca e a aplicação de nitrogenio influenciou apenas a concentraçăo de Ca. Para uma produção media de 10 t.ha-1 de frutos maduros e de 1,3 t.ha-1 de frutos verdes, observou-se uma exportação de aproximadamente $65 \mathrm{~kg}^{-h a^{-1}}$ de

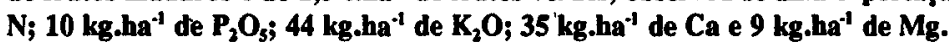

Describores: figueira, irrigação, nitrogênio.

\section{INTRODUCTION}

Fig-tree cultivation in Brazil can be found in the states of São Paulo, Rio Grande do Sul and Minas Gerais, which are the largest producers. In the State of São Paulo its production is practically restricted to the microregion of Campinas, especially in the county of Valinhos. Due to the large scale of manual work involved and to its financial return fig-tree cultivation is extremely interesting from the social point of view.
Among the new agricultural areas, the region of Ilha Solteira has opened great perspectives for the crop, because of its suitable climate, its relatively fertile soil and the great availability of water and electric energy. On the other hand, being a non-traditional crop in the region, accurate studies are needed in order to assist fertilization effects upon nutritional and qualitative aspects for commercial fig crop production.

\footnotetext{
' Research supported by FAPESP (Project Number 89/3242-4).

2 Scholarship student by FAPESP.
} 
Literature concerning fig-treecultivation is scarce. FACHINELLO et al. (1979) reports that from a practical viewpoint there are no special rules on this subject. PROEBSTING \& TATE (1952) observed that foliar concentration of net and total nitrogen decreased during the growing season. Similar results were obtained by PROEBSTING \& WARNER (1954) who noted the decrease of nitrogen and phosphorus contents, while potassium content increased up to half of the growth season and calcium and magnesium contents increased gradually from the beginning to the end of growth season.

BATAGLIA et al. (1985) report that nitrogen fertilization may play an important role not only because of the concentration of nitrogen metabolits, but also because it affects the incorporation of assimilates through the increase of the photosynthetic capacity of the tree.

EL-KASSAS (1975) working with three irrigation levels and three levels of $\mathrm{N}$ fertilization, observed that fig-tree retained $50 \%, 65 \%$ and $80 \%$ available soil water, and presented $1.25 \%, 1.25 \%$ and $1.17 \% \mathrm{~N}$ in the leaves, respectively. The author suggests that the decrease in the concentration and the corresponding increase of water availability in the soil may be related to the large growth of the trees or nitrate leaching in the soil.

Studies developed by HAAG et al. (1979) revealed that fig-trees well supplied with nutrients showed in the leaves: $\mathrm{N}=3.39 \% ; \mathrm{P}=$ $0.17 \%$ to $0,20 \% ; \mathrm{K}=2.86$ to $2.83 \% ; \mathrm{Ca}=1.67$ to $1.91 \% ; \mathrm{Mg}=0.63$ to $0.66 \%$; and $\mathrm{B}=162$ to $219 \mathrm{ppm}$. Other authors working with four irrigation levels $(12.5 \%, 25.0 \%, 37.5 \%$ and $50.0 \%$ of Class A pan evaporation) observed that there was no variation of $\mathrm{N}, \mathrm{P}, \mathrm{Ca}$ and $\mathrm{Mg}$ contents in the leaves, at several seasons in which samples were collected.

HIROCE et al. (1979) observed that for the production of only $20 \mathrm{t}^{-\mathrm{ha}^{-1}}$ of fresh fruit, fig-trees extracted $68.8 \mathrm{~kg}$ of N, $9.4 \mathrm{~kg}$ of $\mathrm{P}_{2} \mathrm{O}_{5}$, $79.3 \mathrm{~kg}$ of $\mathrm{K}_{2} \mathrm{O}, 21.9 \mathrm{~kg}$ of $\mathrm{Ca}$ and $6,1 \mathrm{~kg}$ of $\mathrm{Mg}$. It should be noted that due to the drastic pruning, when about 10 t.ha $^{-1}$ of branches are exported, nutrients are carrying along.

This work aims the evaluation of the effect of six water levels, based on the Class A pan evaporation, and six nitrogen levels upon the quality of figs and their nutritional aspects related to crop management.

\section{MATERIAL AND METHODS}

The experiment was carried out at Ilha Solteira, $335 \mathrm{~m}$ above sea level, in the county of Selviria (20'22'S, 51'22'W), MS, Brazil. According to Köppen's classification the climate type is Aw, presenting an average yearly temperature of $25^{\circ}$ and precipitation of $1330 \mathrm{~mm}$ (CENTURION, 1982).

The soil is a dark-red loamy latosol and a previous chemical analysis indicated: $\mathrm{pH}\left(\mathrm{CaCl}_{2}\right)$ $=4.8 ; \mathrm{MO}=2.8 \% ; \mathrm{P}\left(\mathrm{H}_{2} \mathrm{SO}_{4}\right)=30 \mu \mathrm{g} / \mathrm{cm}^{3} ; \mathrm{K}$, $\mathrm{Ca}, \mathrm{Mg}, \mathrm{H}+\mathrm{Al}, \mathrm{S}, \mathrm{T}$, respectively $0.37,2.7,1.1$, $3.9,4.17,8.07 \mathrm{meq} / 100 \mathrm{~cm}^{3}$ and base saturation (V) $=52 \%$.

Fig trees of the variety "Roxo-de-Valinhos" were obtained through asexual propagation by means of commercial cuttings. This variety is the only one cultivated in the State of São Paulo. The tree is strong, productive and suits quite well to the system of drastic pruning. It is suitable for the production of ripe figs for in natura consumption and immature or not yet fully ripe figs for the industry (FRANCO \& PENTEADO, 1986). Yield is high and fruit is of good quality, both for in natura consumption and industrial processing (RIGITANO \& OJIMA, 1963; SIMÃO, 1971; GOMES, 1975).

Transplant of the rooted cuttings to the experimental plots was done on May 19, 1988, using a $3.0 \times 2.0 \mathrm{~m}$ spacing $(3.0 \mathrm{~m}$ between the rows and $2.0 \mathrm{~m}$ between the trees). Fertilizer was applied to holes, using $1 \mathrm{~kg}$ of dolomitic lime, 500 $\mathrm{g}$ of simple superphosphate, $100 \mathrm{~g}$ of $\mathrm{KCl}$ and 20 liters of fresh manure. After planting the rooted cuttings were managed according to PEREIRA (1981). The experiment started when trees had twelve branches and were in their second commercial harvest.

A mulch of bean straw (Phaseolus vulgaris L.) was used to cover soil surface. Occasional sprouts along the branches were eliminated to keep trees without side sprouting.

Irrigation was performed using microsprinklers, applying water to two plants simultaneously, three times a week. The average precipitation of each microsprinkler was $2.5 \mathrm{~mm} / \mathrm{h}$, tested before the beginning of the experiment. Fertilization was done on August, 20 and October, 10, 1990, with simple superphosphate and potassium chloride in full dosage of 222 and $120 \mathrm{~g}$ per tree, respectively, applied around the plant. 
Six main water treatments were chosen, related to Classe A Pan Evaporation (CAPE), being $\mathrm{Wo}=$ non-irrigated, $\mathrm{W} 1=0.25 \mathrm{CAPE}, \mathrm{W} 2=$ $0.50 \mathrm{CAPE}, \mathrm{W} 3=0.75 \mathrm{CAPE}, \mathrm{W} 4=\mathrm{CAPE}$, $\mathrm{W} 5=1.25 \mathrm{CAPE}$, and six secondary fertilizer treatments, with nitrogen doses: $\mathrm{No}=\mathrm{O}, \mathrm{N} 1=$ $150, \mathrm{~N} 2=300, \mathrm{~N} 3=450, \mathrm{~N} 4=600$ and $\mathrm{N} 5=$ $750 \mathrm{~g} /$ plant, applied monthly, from August to December 1990, using ammonium sulphate.

During the experiment (July, 1990 to March, 1991), the total CAPE was $1590.3 \mathrm{~mm}$. In January and February, irrigations were little frequent due rain excess and in March, they were not provided for the same reason.

The experimental design is a split plot statistical scheme, with six main and six secondary treatments and four replicates. The useful area of each sub-plot was of $12 \mathrm{~m}^{2}$, including two plants. According to this scheme, each row had 6 subplots, each one with 3 trees, two of them used for sampling and one considered as border plant.

During harvest, the pulp/peel ratio and soluble solid content of fruits were analysed four times. The content of soluble solids (Brix) was obtained through the reading in a refractometer with fully ripe figs. Each replicate of these parameters represents the average of aleatorilly picked fruits in each sub-plot. Measurements were made the day after harvest.

For nutritional analysis, leaves were picked on October 18, 1990. Sampling was made at the beginning of fruit season, choosing the first fully expanded leaf from the apex of five branches. Laboratory analysis was made according to SARRUGE (1974).

Along the harvesting season four samplings of ripe fruit were made for nutrient analysis, aiming to determine their export.

\section{RESULTS AND DISCUSSION}

TABLE 1 shows that according to the $F$ test the treatments present no differences. Nevertheless, the regression analysis made on data of January 2, shows a 5\% significance of probability. Increase in nitrogen level also increased the Brix content of the ripe fruit, the fruit presenting a sweeter flavour. The average Brix content of the three later seasons was not more than $11^{\circ}$. This fact shows that to the end of harvest season, leaf fall increases. Consequently, there is a decrease in photosynthastes transferred to the fruit. At the beginning of the harvest the fruit presents best flavor (sweeter), since at a later stage the quantity of leaves tends to be reduced due to physiological features of the species.

CONDIT (1947) reports that ripe fruit presented differences in soluble solid contents, varying from $12^{\circ}$ to $19^{\circ}$, in the first season. Nevertheless this difference may be related to the region of cultivation and to the stage of maturation of the fruit at harvesting time. The high precipitation which occured in Summer induced a major incidence of rust, which caused greater leave fall. This fact may have influenced the quality of the fruits.

With respect to the pulp/peel relation for January samples, there was a significant interaction between doses of $\mathrm{N}$ and water supply. Data were adjusted to a quadratic function, but the regression deviation was also significant. Average values for the pulp/peel relation were found ranging from 89 to $92 \%$ of pulp and 8 to $11 \%$ of peel. CONDIT (1947) found values of $84 \%$ in the pulp and $16 \%$ in the peel. In the current experiment fruits have presented a larger percentage of pulp comparing to the cited author, corresponding to thin peel fruits, more suitable for consumption in natura. On the other hand, such thin peel fruits have a shorter market life.

With respect to nutrient analysis, there was significance for phosphorus and calcium contents, due to the different water supply. Nitrogen dosage influenced calcium content. By regression analysis it was observed that water supply influenced $\mathrm{N}$ and $\mathrm{Ca}$ contents in the leaves of fig-trees (Figure 1). Water has increased the absorption of $\mathrm{N}$ and $\mathrm{Ca}$ by the plants. The same did not happen in relation to phosphorus, whose value was reduced when water supply increased. Data here presented differ from those presented by EL-KASSAS (1975), since the water supply did not decrease nutrient content. On the contrary, it increased the content of nutrients in the leaves.

$\mathrm{N}$ doses influenced only $\mathrm{Ca}$ contents (Figure 2). In this case $\mathrm{N}$ may have an antagonistic influence. Comparing HAAG et al. (1979) results with the average values of this experiment, $N$ and $P$ contents were higher, while $\mathrm{K}, \mathrm{Ca}$ and $\mathrm{Mg}$ contents were of the same order.

From the nutritional point of view, analysis made on ripe fruit, at four different stages along the harvest, it was possible to calculate the average export of nutrients by fresh fruit: $20.5 \mathrm{~kg}$ $\mathrm{N}, 2.2 \mathrm{~kg} \mathrm{P}_{2} \mathrm{O}_{5}, 26.7 \mathrm{~kg} \mathrm{~K}_{2} \mathrm{O}, 4.6 \mathrm{~kg} \mathrm{Ca}$ and 1.8 $\mathrm{kg} \mathrm{Mg}$, for an average production of $10 \mathrm{t}^{\text {.ha }} \mathrm{h}^{-1}$. 
TABLE 1 - Averages, F test values and coefficients of variation (C.V.), of soluble solid (Brix) content, Pulp/Peel (P/P) ratio in ripe fruits in different seasons and nutrient content within fig leaves on October 18, 1990.

\begin{tabular}{|c|c|c|c|c|c|c|c|c|c|c|c|c|}
\hline \multirow{3}{*}{$\begin{array}{l}\text { Source of } \\
\text { Variation }\end{array}$} & \multirow{3}{*}{ DF } & \multicolumn{6}{|c|}{ SEASONS } & \multicolumn{4}{|c|}{ NUTRIENTS } & \multirow{3}{*}{$\mathbf{M}_{\mathbf{B}}$} \\
\hline & & \multicolumn{2}{|c|}{ JAN/02/1991 } & \multicolumn{2}{|c|}{ JAN/16/1991 } & \multicolumn{2}{|c|}{ FEB/13/1991 } & \multirow[t]{2}{*}{$\mathbf{N}$} & \multirow[t]{2}{*}{$\mathbf{P}$} & \multirow{2}{*}{$\%$} & \multirow[t]{2}{*}{ Ca } & \\
\hline & & BRIX & $\mathbf{P} / \mathbf{P}$ & BRD & $\mathbf{P} / \mathbf{P}$ & BRD & $\mathbf{P} / \mathbf{P}$ & & & & & \\
\hline $\mathbf{w}$ & 5 & $0.70 \mathrm{~ms}$ & $0.35 \mathrm{~m}$ & $0.58 \mathrm{~ns}$ & $2.38 \mathrm{~ns}$ & $0.87 \mathrm{as}$ & $1.60 \mathrm{~ns}$ & $1.33 \mathrm{~m}(2)$ & $4.05^{m}(3)$ & $0.72 \mathrm{~ns}$ & $4.79 \cdots(4)$ & $0.89 \mathrm{~ns}$ \\
\hline $\mathbf{N}$ & 5 & $2.06 \mathrm{~ms}(1)$ & $1.17 \mathrm{me}$ & $0.16 n$ & $0.72 \mathrm{~m}$ & $2.07 n s$ & $0.64 n$ & $0.52 \mathrm{ng}$ & $0.79 n$ & $0.9 \mathrm{lns}$ & $3.14^{*}(5)$ & $1.91 \mathrm{~ns}$ \\
\hline $\mathbf{W} \times \mathbf{N}$ & 25 & $1.21 \mathrm{~ns}$ & $0.75 \mathrm{~ns}$ & $1.50 \mathrm{~ns}$ & $1.93^{*}$ & $1.10 \mathrm{~ns}$ & $1.38 \mathrm{~ns}$ & $092 \mathrm{~ns}$ & 0.90 & $1.00 \mathrm{~ns}$ & $0.87 \mathrm{~ns}$ & $1.42 \mathrm{~ns}$ \\
\hline C.V.\% (W) & & 13.58 & 25.61 & 11.14 & 10.48 & 12.22 & 3360 & 15.92 & 8.42 & 11.63 & 9.46 & 1711 \\
\hline C.V.\% (N) & & 10.86 & 21.07 & 8.01 & 19.33 & 8.14 & 16.80 & 8.52 & 4.85 & 8.72 & 7.19 & 10.02 \\
\hline $\mathrm{Wo}=1119 \mathrm{~mm}$ & & 14.55 & 9.76 & 10.11 & 10.37 & 10.19 & 8.37 & 3.45 & 0.50 & 2.29 & 1.29 & 043 \\
\hline$W 1=1371_{\mathrm{mm}}$ & & 14.30 & 10.08 & 10.65 & 10.86 & 10.49 & 10.36 & 3.65 & 0.50 & 2.24 & 1.28 & 0.40 \\
\hline$W_{2}=1617 \mathrm{~mm}$ & & 14.29 & 9.78 & 10.35 & 10.38 & 10.63 & 8.57 & 3.76 & 047 & 2.29 & 1.30 & 040 \\
\hline $\mathrm{W} 3=1871_{\mathrm{mm}}$ & & 14.65 & 9.59 & 1042 & 1146 & 10.60 & 9.47 & 3.79 & 0.49 & 2.23 & 1.31 & 0.42 \\
\hline $\mathrm{W} /=2121 \mathrm{~mm}$ & & 1488 & 10.45 & 10.32 & 1070 & 10.40 & 9.64 & 3.76 & 0.47 & 2.17 & 1.39 & 0.40 \\
\hline$W S=2371_{\mathrm{mm}}$ & & 13.92 & 10.06 & 10.30 & 11.42 & 10.04 & 10.19 & 3.83 & 0.46 & 2.24 & 1.41 & 0.43 \\
\hline NO $=0$ & & 14.29 & 10.71 & 10.25 & 10.86 & 10.41 & 9.74 & 3.65 & 0.48 & 2.26 & 1.37 & 040 \\
\hline $\mathrm{Nl}=150_{\mathrm{B}}$ & & 13.89 & 968 & 10.39 & 10.74 & 10.16 & 9.26 & 3.70 & 0.48 & 2.26 & 1.36 & 0.40 \\
\hline $\mathrm{N} 2=300_{\mathrm{B}}$ & & 14.12 & 9.66 & 10.36 & 11.58 & 10.52 & 9.27 & 3.70 & 0.48 & 2.25 & 1.34 & 0.42 \\
\hline $\mathrm{N3}=450_{\mathrm{B}}$ & & 14.55 & 10.28 & 10.33 & 10.78 & 10.22 & 9.39 & 3.66 & 048 & 2.19 & 1.32 & 0.42 \\
\hline$N 4=6008$ & & 15.23 & 9.47 & 10.34 & 10.59 & 10.22 & 9.77 & 3.76 & 0.49 & 2.21 & 1.31 & 0.43 \\
\hline NS $=750_{\mathrm{g}}$ & & 14.52 & 992 & 10.45 & 1064 & 10.81 & 9.18 & 3.76 & 049 & 2.26 & 1.27 & 0.41 \\
\hline
\end{tabular}

W = Total Water supply (irrigation + rain)

$\mathbf{N}=$ Nitrogen

D.F. = Degrees of freedom

$\mathrm{ns}=$ non significant

* = significant at $P=0.05$

** = significant at $P=0.01$

Nutrient export related to the production of $1,300 \mathrm{~kg} \cdot \mathrm{ha}^{-1}$ of green fruit was of about $11.6 \mathrm{~kg} \mathrm{~N}, 1.2 \mathrm{~kg} \mathrm{P}_{2} \mathrm{O}_{3}, 11.0 \mathrm{~kg} \mathrm{~K}_{2} 0,4.4 \mathrm{~kg}$ $\mathrm{Ca}$ and $1.7 \mathrm{~kg} \mathrm{Mg}$ and the export of nutrients through the branches of the plants $(5.6 \mathrm{~kg} / \mathrm{plant})$ was about $32.9 \mathrm{~kg} \mathrm{~N}, 6.6 \mathrm{~kg} \mathrm{P}_{2} \mathrm{O}_{3}, 31.1 \mathrm{~kg} \mathrm{~K}_{2} \mathrm{O}$, $25.9 \mathrm{~kg} \mathrm{Ca}$ and $5.6 \mathrm{~kg} \mathrm{Mg}$ per hectare of fig-tree plantation, totalizing an export of $65 \mathrm{~kg}$ of $\mathrm{N}$,
$10 \mathrm{~kg} \mathrm{P} \mathrm{O}_{s}, 44 \mathrm{~kg} \mathrm{~K} \mathrm{O}_{2}, 35 \mathrm{~kg} \mathrm{Ca}, 9 \mathrm{~kg} \mathrm{Mg}$ in an hectare of fig-orchard.

Values presented above were calculated from nutrient concentration in nonirrigated trees, which have received $300 \mathrm{~g}$ of $\mathrm{N} /$ tree. The results are not in accordance with HIROCE et al. (1979) who indicate a larger export. 


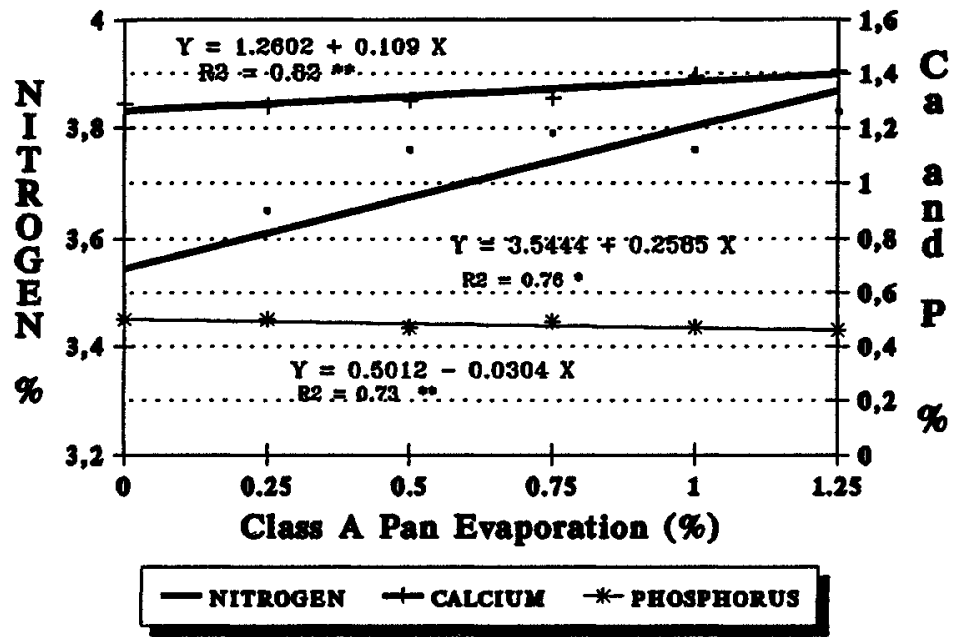

Figure 1 - Nitrogen, phosphorus and calcium leaf levels related to water supply - Harvest $1990 / 1991$.

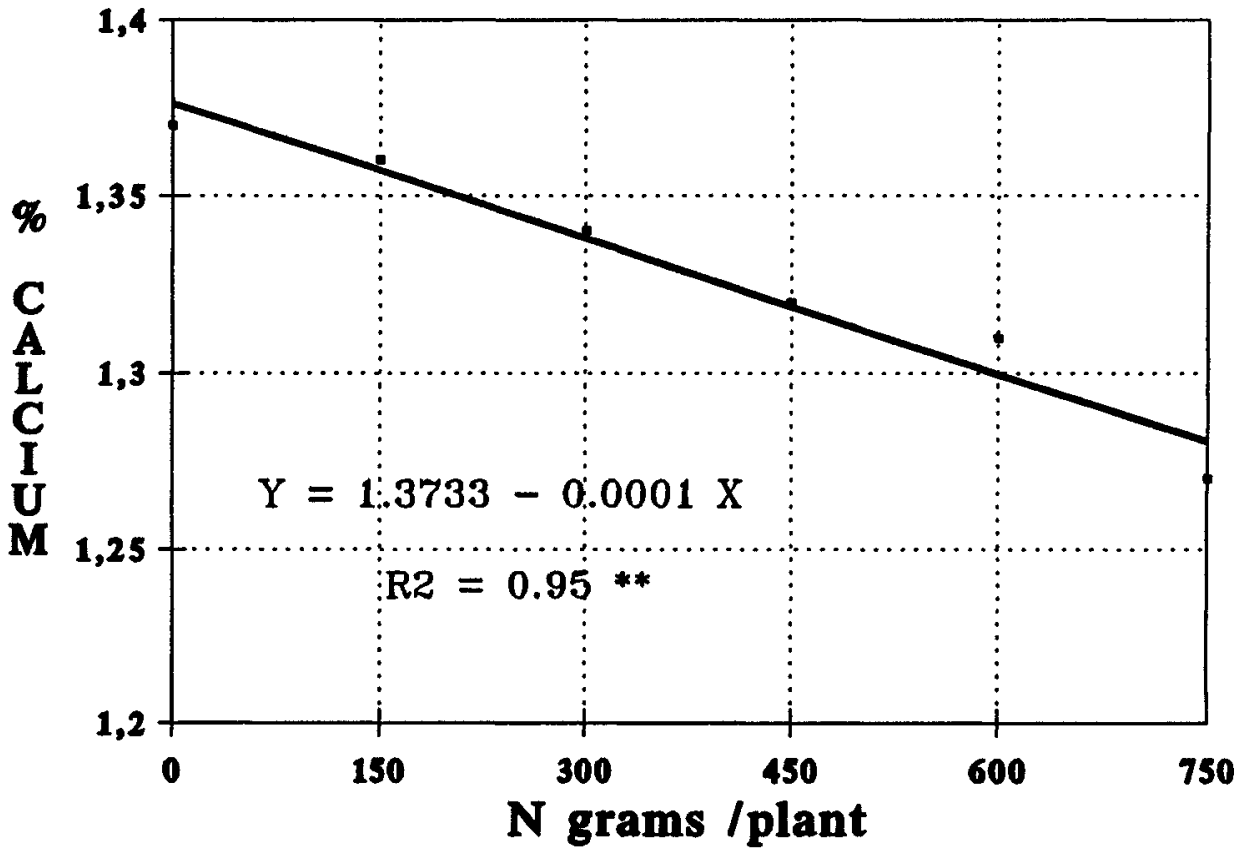

Figure 2 - Calcium leaf level related to nitrogen doses. Harvest 1990/1991.

Sci. agric., Piracicaba, 51(2):292-297, maio/ago., 1994 


\section{CONCLUSION}

It is concluded that:

- only nitrogen has shown positive effect on the Brix, for only one analysed period;

- considering leaf analysis, irrigation increased leaf $\mathrm{N}$ and $\mathrm{Ca}$ contents and decreased $\mathrm{P}_{2} \mathrm{O}_{5}$ contents. $\mathrm{N}$ has caused a reduction in $\mathrm{Ca}$ content. $\mathrm{P}$ and $\mathrm{Mg}$ were not influenced by treatments;

- the total export of nutrients for the production of $10 \mathrm{t}$ of ripe fruit and $1.3 \mathrm{t}$ of green fruit was of about $65 \mathrm{~kg}$ of $\mathrm{N}, 10 \mathrm{~kg}$ of $\mathrm{P}_{2} \mathrm{O}_{3}, 44 \mathrm{~kg}$ of $\mathrm{K}_{2} \mathrm{O}, 35$ $\mathrm{kg}$ of $\mathrm{Ca}, 9 \mathrm{~kg}$ of $\mathrm{Mg}$ in one hectare of fig-trees; and,

- fig-tree crop is well adapted to the new region, producing fruit of good quality even if nonirrigated, but mulch must be present.

\section{ACKNOWLEDGMENTS}

The financial assistance of FAPESP and colaborations of Salatiér Buzetti, Walter Valério Valeriano Filho and Braz Hernandez Filho are gratefully acknowledged.

\section{REFERENCES}

BATAGLIA, O. C.; QUAGGIO, J. A.; BRUNINI, O.; CIARELLI, D.M. A adubação nitrogenada e ajustamento osmótico em milho e sorgo. Pesquisa Agropecuária Brasileira, Brasinlia, v.20, n.6, p.659-665, 1985 .

CENTURION, J.F. Balanço hídrico na regiāo de Itha Solteira. Cientifica, São Paulo, v.10, n.1, p.57-61, 1982.

CONDIT, I.J. The fig. Massachusetts: Chronic Botanic, 1947. 222p.

EL-KASSAS, S.E. Effect of soil moisture levels and nitrogen fertilization on yield, shoot growth and leaf composition on fig trees. Annals of Agricultural Science of Moshtohor, Assuit, v.4, p.155-186, 1975.
FACHINELLO, J.C.; MANICA, 1.; MACHADO, A.A. Resposta da figueira (Ficus carica L) cv. São Pedro a dois niveis de adubação com nitrogênio, fósforo e potássio. In: CONGRESSO BRASILEIRO DE FRUTICULTURA, 5., 1979, Pelotas. Anais... Pelotas:SBF, 1979. p.889-895.

FRANCO, J.A.M.; PENTEADO, S.R. Cultura da figueira. In: PENTEADO, S.R. Fruticultura de clima temperado em São Paulo. Campinas: Fundação Cargill, 1986. cap.5, p.113-129.

GOMES, R.P. Fruticultura brasileira. 2,ed. São Paulo: Nobel, 1975. 446p.

HAAG, H.P.; OLIVEIRA, G.D.; ROCHA FILHO, J.V.; SILVA, D.H. Distúrbios nutricionais em figueira (Ficus carica L.) cultivada em solução nutritiva. $\mathbf{O}$ Solo, Piracicaba, v.71, n.1, p.31-34, 1979.

HIROCE, R.; OJIMA, M.; GALLO, J.R.; BATAGLIA, O.C.; FURLANI, P.R.; FURLANI, A.M. Composição mineral exportação de nutrientes pelas colheitas de frutos sub-tropicais e temperados. In: CONGRESSO BRASILEIRO DE FRUTICULTURA, 5., 1979, Pelotas. Anais... Pelotas: SBF, 1979. p.179-189.

PEREIRA, F.M. Cultura da figueira. São Paulo: Livroceres, 1981.73p.

PROEBSTING, E.L.; TATE, R. Seasonal changes in nitrate content of fig leaves. Proceedings of the American Society for Horticultural Science, Alexandria, n.60, p.7-10, 1952.

PROEBSTING, E.L.; WARNER, R.M. The effect of fertizers on yield, quality and leaf composition of figs. Proceedings of the American Society for Horticultural Science, Alexandria, v.63, p.8-10, 1954.

RIGITANO, O.; OJIMA, M. Época de poda da figueira cultivada no Estado de São Paulo. Bragantia, Campinas, v.22, n.42, p.529-536, 1963.

SARRUGE, J.R.; HAAG, H.P. Anallise química em plantas. Piracicaba: ESALQ/USP, 1974. 56p.

SIMĀO, S. Manual de fruticultura. São Paulo: Agronômica Ceres, 1971.530p.

Enviado para publicação em 13.12 .93

Aceito para publicação e, 02.05.94 